\title{
KESESUAIAN MATERI APRESIASI SASTRA \\ PADA BUKU TEKS BAHASA INDONESIA SMP \\ KURIKULUM 2013
}

\author{
MEINA FEBRIANI \\ Universitas Negeri Semarang \\ meinafebri@mail.unnes.ac.id
}

Pertama Diterima: 3 Desember 2018

Bukti Akhir Diterima: 10 Desember 2018

\begin{abstract}
Abstrak
Penelitian ini bertujuan untuk mengungkap kesesuaian materi apresiasi sastra pada buku teks pelajaran Bahasa Indonesia Kurikulum 2013 (Revisi 2016) tingkat SMP. Keberadaan buku ajar atau buku teks Bahasa Indonesia tidak bisa lepas dari kurikulum yang diberlakukan. Perubahan kurikulum yang dilakukan selama ini berdampak langsung pada buku teks. Pada saat ini masih ditemukan materi yang tidak sesuai dengan standar isi pada kurikulum yang berlaku, meski buku teks tersebut diterbitkan oleh Pusat Kurikulum dan Perbukuan. Salah satu materi pada mata pelajaran Bahasa Indonesia yakni apresiasi sastra. Penelitian ini menggunakan pendekatan kualitatif dengan metode deskriptif. Data yang dianalisis adalah buku teks bahasa Indonesia SMP Kurikulum 2013 (edisi revisi). Sumber data berupa wacana tertulis dalam buku teks Bahasa Indonesia untuk jenjang SMP dalam kurikulum 2013 edisi revisi 2016. Data dikumpulkan melui teknik utama studi dokumen. Dokumen berupa (1) buku teks Bahasa Indonesia untuk jenjang SMP dalam kurikulum 2013 edisi revisi 2016, (2) Standar Isi Kurikulum 2013 edisi revisi 2016, dan (3) dokumen lain yang mendukung. Hasil penelitian ini menunjukkan bahwa keseuaian materi apresiasi sastra (puisi, prosa, dan drama) memperoleh kriteria "kurang" dengan nilai rerata 2,86 (skala 0-4). Beberapa hal yang menjadi temuan kekurangan tersebut antara lain: (1) penjabaran materi yang tidak lengkap dari indikator yang dikembangkan, (2) penjabaran materi tidak sesuai indikator, (3) ketidakkonsistenan contoh penjelas dengan konsep yang disampaikan, (4) kegiatan yang dilakukan tidak sesuai indikator, dan (5) beberapa bagian tidak ada contoh penjelas.
\end{abstract}

Kata kunci: pembelajaran apresiasi sastra, buku teks Bahasa Indonesia SMP, Kurikulum 2013

\section{Abstract}

This study aims to reveal the appropriateness of literature appreciation material in the 2013 Indonesian Language Curriculum textbook (Revised 2016) at the junior 
high school level. The existence of textbooks or Indonesian language textbooks cannot be separated from the applied curriculum. Changes of curriculum have an impact directly on the textbook. At this time material is still found that is not in accordance with the content standards in the applicable curriculum, even though the textbook is published by the Center for Curriculum and Books. One of the material on Indonesian language subjects is literary appreciation. In its implementation, literary appreciation learning is still experiencing obstacles. This study uses a qualitative approach with descriptive methods. The data analyzed were Indonesian SMP textbooks 2013 Curriculum (revised edition). Data sources are in the form of discourse written in Indonesian textbooks for junior high school level in the 2013 revised edition of the 2016 curriculum. Data is collected through the main techniques of document study. Documents in the form of (1) Indonesian language textbooks for junior high school level in the 2016 revised edition of the curriculum in 2013, (2) Revised 2013 Curriculum Content, and (3) other supporting documents. The results of this study indicate that the compatibility of literary appreciation material (poetry, prose, and drama) obtained the criteria of "less" with an average value of 2.86 (scale 0-4). Some of the findings of these deficiencies include: (1) the elaboration of incomplete material from the indicators developed, (2) the elaboration of material not according to indicators, (3) inconsistency in explanatory examples with the concepts presented, (4) activities carried out not according to indicators, and (5) some parts there are no explanatory examples.

Keywords: literary appreciation learning, SMP Indonesian textbooks, 2013 curriculum

\section{PENDAHULUAN}

Buku memiliki peranan penting dalam kegiatan belajar mengajar dan pengembangan ilmu pengetahuan. Dalam kegiatan belajar mengajar (KBM) antara guru dengan siswa tidak akan terlepas pada penggunaan buku teks. Buku teks merupakan salah satu bahan belajar siswa yang berisi materi pelajaran dan digunakan untuk membantu guru dan siswa dalam melaksanakan kegiatan belajar mengajar. Salah satu hal yang penting dalam buku pelajaran adalah materi pembelajaran.

Salah satu faktor penentuan keberhasilan guru dan siswa dalam menggunakan buku ditentukan oleh kualitas buku teks. Di dalam pengukuran kualitas buku teks harus diperhatikan aspek-aspek penting yaitu kesesuaian muatan materi dengan kurikulum, keruntutan materi, kedalaman dan keluasan materi. Sebagai acuan ada tiga prinsip yang perlu diperhatikan dalam penyusunan buku teks atau materi pembelajaran. Amri (2013) menyatakan bahwa prinsip-prinsip dalam pemilihan bahan/ materi pelajaran untuk buku ajar meliputi prinsip relevansi, konsistensi, dan kecukupan.

Keberadaan buku teks tidak bisa lepas dari kurikulum yang diberlakukan. Perubahan kurikulum yang dilakukan selama ini berdampak langsung pada buku teks. Pada saat kurikulum lama diganti isi atau materi buku teks pun harus disesuaikan dengan kurikulum baru. Namun, tak jarang masih ditemukan materi yang tidak sesuai dengan kurikulum berlaku meski buku teks tersebut diterbitkan 
oleh Pusat Kurikulum dan Perbukuan.

Berkaitan dengan materi ajar, salah satu aspek yang dibelajarkan dalam mata pelajaran Bahasa Indonesia, yakni materi pembelajaran sastra. Tujuan pembelajaran secara umum tersebut dijabarkan lagi dalam beberapa tujuan khusus. Tujuan khusus yang terkait dengan pengetahuan sastra, yaitu siswa dapat menikmati dan memanfaatkan karya sastra untuk memperluas wawasan, memperhalus budi pekerti, serta meningkatkan pengetahuan dan kemampuan berbahasa. Selain itu, dari pembelajaran sastra siswa diharapkan dapat menghargai dan membanggakan sastra Indonesia sebagai khazanah budaya dan intelektual manusia Indonesia.

Pembelajaran apresiasi sastra pada hakikatnya merupakan upaya untuk menanamkan rasa peka kepada siswa terhadap cita rasa sastra. Seharusnya pengajaran apresiasi sastra yang disampaikan guru kepada siswa mampu mengubah sikap siswa dari tak acuh menjadi lebih bersimpati terhadap sastra. Hal tersebut disebabkan materi sastra yang disuguhkan tidak sekadar representation oflife (Imitation of life) melainkan interpretation of life (Endraswara, 2002:7). Dengan demikian, karya sastra harus dipahami sebagai fenomena yang tidak hanya sekedar memuaskan emosi melainkan memercikkan ide-ide dan pikiran. Karya sastra sebagai salah satu kebutuhan manusia menawarkan kisi-kisi kemanusian yang indah menuju kesempurnaan hidup.

Kajian teori yang digunakan dalam penelitian ini yakni: (1) buku teks pelajaran Bahasa Indonesia, (2) aspek kelayakan buku teks pelajaran, (3) apresiasi sastra, dan (4) standar isi Kurikulum 2013. Pertama, menurut Muslich (2010:50), buku teks adalah buku yang berisi uraian bahan tentang mata pelajaran atau bidang studi tertentu, yang disusun secara sistematis dan telah diseleksi berdasarkan tujuan tertentu, orientasi pembelajaran, dan perkembangan siswa untuk diasimilasikan. Berdasar pendapat tersebut, buku teks digunakan untuk mata pelajaran tertentu. Penggunaan buku teks tersebut didasarkan pada tujuan pembelajaran yang mengacu pada kurikulum. Selain menggunakan buku teks, pengajar dapat menggunakan sarana-sarana atau pun teknik yang sesuai dengan tujuan yang sudah dibuat sebelumnya. Penggunaan yang memadukan buku teks, teknik serta sarana lain ditujukan untuk mempermudah pemakai buku teks terutama peserta didik dalam memahami materi.

Kedua, $D i$ dalam mengembangkan buku teks, perlu diperhatikan komponen utama buku teks berkualitas. Komponen-komponen itu meliputi (1) komponen materi atau isi buku; (2) komponen penyajian; (3) komponen bahasa dan keterbacaan; dan (4) komponen grafika (Puskurbuk, 2008:55). Kriteria komponen tersebut berfungsi sebagai rambu-rambu penulisan. Kreativitas dan inovasi pengembangan buku teks tetap menjadi ciri khas penulis.

Ketiga, Apresiasi diserap dari bahasa Inggris apreciation yang berarti pertimbangan, penilaian, pemahaman dan pengenalan yang tepat. Apresiasi mengandung makna pengenalan melalui perasaan atau kepekaan batin pemahaman dan pengakuan terhadap nilai-nilai keindahan yang diungkap pengarang.

Apresiasi menurut Gove (dalam Haryati, 2013:1)mengandung makna (1) pengenalan melalui perasaan atau kepekaan batin dan (2) pemahaman dan pengakuan terhadap nilai-nilai keindahan yang diungkapkan pengarang. Pada sisi lain, Squire dan Taba (dalam Aminudin 2002:35) berkesimpulan bahwa sebagai suatu proses apresiasi melibatkan tiga unsur inti yakni aspek kognitif, aspek emotif, dan evaluatif. 
Aspek kognitif berkaitan dengan keterlibatan intelektual pembaca dalam usaha memahami unsur-unsur sastra yang bersifat objektif. Unsur dalam karya sastra yang bersifat objektif disebut dengan unsur intrinsik. Unsur karya sastra yang berada di luar teks disebut ekstrinsik. Kegiatan yang dilakukan untuk memahami atau mengintreprestasikan unsur-unsur yang terkandung dalam teks. Aspek emotif adalah aspek yang berkaitan dengan emosi pembaca dalam upayanya menghayati unsurunsur keindahan teks sastra. Aspek evaluatif berhubungan dengan kegiatan memberikan penilaian terhadap baik, buruk, indah, tidak indah, sesuai atau tidak sesuai serta sejumlah ragam penilaian lain yang tidak harus hadir dalam sebuah karya kritik, tetapi secara personal dimiliki oleh pembaca.

Sejalan dengan hal tersebut, kegiatan apresiasi dapat tumbuh dengan baik jika pembaca mampu menumbuhkan rasa akrab dengan teks yang diapresiasinya, menumbuhkan sikap sungguh-sungguh, serta melaksanakan kegiatan itu sebagai bagian dari hidupnya, sebagai suatu kebutuhan yang mampu memuaskan rohaninya.

Baribin(1990:15-16) mengemukakan tentang tingkat-tingkat apresiasi sastra dengan penjelasan sebagai berikut. (1) Apresiasi tingkat pertama terjadi apabila seseorang mengalami pengalaman yang ada dalam sebuah karya. Ia terlibat secara intelektual, emosional, dan imajinatif dengan karya itu. Dalam peristiwa seperti itu, pikiran, perasaan, dan khayal seseorang untuk melakukan kegiatan sesuai dengan yang diinginkan oleh penciptanya. (2) Apresiasi tingkat kedua terjadi apabila daya intelektual pembaca bekerja lebih giat. Pada tingkat ini pembaca mulai bertanya pada dirinya sendiri tentang makna pengalaman yang didapatnya dari karya sastra itu. (3) Apresiasi tingkat ketiga, pembaca menyadari bahwa suatu karya sastra adalah gejala yang bersifat historis. Karya sastra yang diciptakan tidak lepas dari faktor waktu dan tempat, bahkan merupakan ungkapan dari jalinan pengaruh faktor itu yang berlaku terhadap jiwa dan kepribadian sastrawan.

Jadi, Apresiasi sastra merupakan salah satu media yang efektif untuk meningkatkan apresiasi sastra peserta didik. Pembelajaran sastra sebagai salah satu bentuk pembelajaran bahasa dan sastra Indonesia di tingkat SMP merupakan formula pembelajaran yang cocok diaplikasikan untuk meningkatkan kemampuan kognitif, psikomotor, dan afektif peserta didik.

Keempat, Standar Isi Mata Pelajaran Bahasa Indonesia SMP yang terdapat pada Permendikbud Nomor 24 Tahun 2016 Lampiran 2 Tentang Kompetensi Inti dan Kompetensi Dasar Bahasa Indonesia SMP. Tujuan kurikulum mencakup empat kompetensi, yaitu (1) kompetensi sikap spiritual, (2) sikap sosial, (3) pengetahuan, dan (4) keterampilan. Kompetensi tersebut dicapai melalui proses pembelajaran intrakurikuler, kokurikuler, dan/atau ekstrakurikuler.

Adapun Kompetensi Dasar yang meliputi kemampuan mengapresiasi karya sastra (puisi, prosa, dan drama) pada jenjang SMP, sebagai berikut.

\section{Tabel 1. Komepetensi Dasar Apresiasi Sastra pada Buku Teks SMP}

\begin{tabular}{|c|l|c|}
\hline No & \multicolumn{1}{|c|}{ KD } & $\begin{array}{c}\text { Jenis Karya } \\
\text { Sastra }\end{array}$ \\
\hline 1 & $\begin{array}{l}\text { Kelas VII, KD 3.13 Mengidentifikasi informasi (pesan, rima, dan pilihan } \\
\text { kata) dari puisi rakyat (pantun, syair, dan bentuk puisi rakyat setempat) } \\
\text { yang dibaca dan didengar }\end{array}$ & Puisi \\
\hline
\end{tabular}




\begin{tabular}{|c|c|c|}
\hline No & KD & $\begin{array}{c}\text { Jenis Karya } \\
\text { Sastra }\end{array}$ \\
\hline 2 & $\begin{array}{l}\text { Kelas VII, KD } 3.14 \text { Menelaah struktur dan kebahasaan puisi rakyat } \\
\text { (pantun, syair, dan bentuk puisi rakyat setempat) yang dibaca dan didengar }\end{array}$ & Puisi \\
\hline 3 & $\begin{array}{l}\text { Kelas VIII KD 3.7 Mengidentifikasi unsur-unsur pembangun teks puisi } \\
\text { yang diperdengarkan atau dibaca }\end{array}$ & Puisi \\
\hline 4 & $\begin{array}{l}\text { Kelas VIII KD 4.7 Menyimpulkan unsur-unsur pembangun dan makna } \\
\text { teks puisi yang diperdengarkan atau dibaca }\end{array}$ & Puisi \\
\hline 5 & $\begin{array}{l}\text { Kelas VIII KD } 3.8 \text { Menelaah unsur-unsur pembangun teks puisi } \\
\text { (perjuangan, lingkungan hidup, kondisi sosial, dan lain-lain) yang } \\
\text { diperdengarkan atau dibaca. }\end{array}$ & Puisi \\
\hline 6 & $\begin{array}{l}\text { Kelas VII, KD 3.3, mengidentifikasi unsur-unsur teks narasi (cerita } \\
\text { imajinasi) yang dibaca dan didengar }\end{array}$ & Prosa \\
\hline 7 & $\begin{array}{l}\text { Kelas VII, KD 3.4, menelaah struktur dan kebahasaan teks narasi (cerita } \\
\text { imajinasi) yang dibaca dan didengar }\end{array}$ & Prosa \\
\hline 8 & $\begin{array}{l}\text { Kelas VII, KD 3.15, mengidentifikasi informasi tentang fabel/legenda } \\
\text { daerah setempat yang dibaca dan didengar }\end{array}$ & Prosa \\
\hline 9 & $\begin{array}{l}\text { Kelas VII, KD 3.16, menelaah struktur dan kebahasaan fabel/legenda } \\
\text { daerah setempat yang dibaca dan didengar }\end{array}$ & Prosa \\
\hline 10 & $\begin{array}{l}\text { Kelas VIII, KD 3.17, menggali dan menemukan informasi dari buku fiksi } \\
\text { dan nonfiksi yang dibaca }\end{array}$ & Prosa \\
\hline 11 & $\begin{array}{l}\text { Kelas IX KD } 3.5 \text { Mengidentifikasi unsur pembangun karya sastra dalam } \\
\text { teks cerita pendek yang dibaca atau didengar }\end{array}$ & Prosa \\
\hline 12 & $\begin{array}{l}\text { Kelas IX KD } 4.5 \text { Menyimpulkan unsur-unsur pembangun karya sastra } \\
\text { dengan bukti yang mendukung dari cerita pendek yang dibaca atau } \\
\text { didengar }\end{array}$ & Prosa \\
\hline 13 & $\begin{array}{l}\text { Kelas IX KD } 3.6 \text { Menelaah struktur dan aspek kebahasaan cerita pendek } \\
\text { yang dibaca atau didengar }\end{array}$ & Prosa \\
\hline 14 & $\begin{array}{l}\text { Kelas IX KD } 3.11 \text { Mengidentifikasi isi ungkapan simpati, kepedulian, } \\
\text { empati, atau perasaan pribadi dari teks cerita inspiratif yang dibaca dan } \\
\text { didengar }\end{array}$ & Prosa \\
\hline 15 & $\begin{array}{l}\text { Kelas IX KD 4.11Menyimpulkan isi ungkapan simpati, kepedulian, } \\
\text { empati atau perasaan pribadi dalam bentuk cerita inspiratif yang dibaca } \\
\text { dan didengar }\end{array}$ & Prosa \\
\hline 16 & $\begin{array}{l}\text { Kelas IX KD } 3.12 \text { Menelaah struktur, kebahasaan, dan isi teks cerita } \\
\text { inspiratif }\end{array}$ & Prosa \\
\hline 17 & $\begin{array}{l}\text { Kelas VIII, KD 3.15, Mengidentifikasi unsur-unsur drama (tradisional } \\
\text { dan moderen) yang disajikan dalam bentuk pentas atau naskah }\end{array}$ & Drama \\
\hline 18 & $\begin{array}{l}\text { Kelas VIII, KD } 4.15 \text {, Menginterpretasi drama (tradisional dan modern) } \\
\text { yang dibaca dan ditonton/didengar }\end{array}$ & Drama \\
\hline 19 & $\begin{array}{l}\text { Kelas VIII, KD 3.16, Menelaah karakteristik unsur dan kaidah kebahasaan } \\
\text { dalam teks drama yang berbentuk naskah atau pentas }\end{array}$ & Drama \\
\hline
\end{tabular}


Kenyataan lain membuktikan bahwa yang menjadi kendala pembelajaran apresiasi sastra di sekolah adalah pemanfaatan buku yang tersedia di lapangan yang terbatas. Dalam konteks ini, buku teks yang beredar di lingkup pendidikan saat ini, yakni buku teks Kurikulum 2013. Dilema yang mungkin muncul yakni, apakah buku teks tersebut sesuai dengan Kompetensi Dasar pada kurikulum 2013? Berdasarkan latar belakang tersebut, akan dilakukan pengkajian secara mendalam terkait kesesuaian materi ajar apresiasi sastra dalam buku teks pelajaran Bahasa Indonesia Kurikulum 2013 tingkat SMP.

\section{METODE PENELITIAN}

Penelitian merupakan penelitian kualitatif dengan analisis konten deskriptif. Menurut Barelson (dalam Darmiyati, 1993: 1) analisis konten adalah teknik analisis untuk menghasilkan deskripsi yang objektif, sistematik, dan bersifat kuantitatif mengenai isi yang terungkap dalam komunikasi.

Moleong (2007: 220) menyebut analisis konten sebagai kajian isi. Kajian isi merupakan metodologi penelitian yang memanfaatkan seperangkat prosedur untuk menarik simpulan yang sahih dari sebuah buku atau dokumen. Analisis konten mencakup analisis pada tataran bentuk dan kedalaman isi dari objek yang diteliti. Penelitian ini menggunakan analisis konten deskriptif jadi tidak menyentuh kedalaman isi sampai aspek makna, karena aspek tersebut dikaji lebih lanjut dengan analisis konten inferensial.

Desain penelitian untuk mengatahui tahapan-tahapan penelitian ini digambarkan dalam bentuk diagram sebagai berikut.

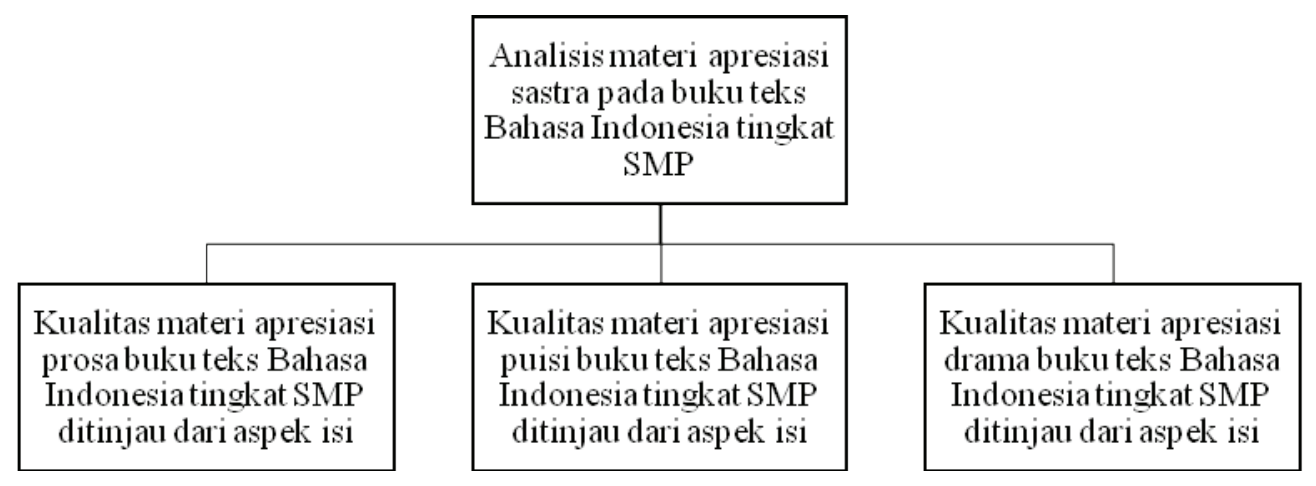

Gambar 1 Diagram Desain Penelitian

Data penelitian ini berupa informasi-informasi dokumen yang bersifat kualitatif. Sumber data berupa wacana tertulis dalam buku teks bahasa Indonesia untuk jenjang SMP dalam Kurikulum 2013 edisi revisi 2016. Data dikumpulkan melui teknik utama studi dokumen. Dokumen berupa (1) buku teks bahasa Indonesia untuk jenjang SMP dalam Kurikulum 2013 edisi revisi 2016 (Kepmendikbud Nomor 116/P/2016 tentang Penetapan Buku Teks Pelajaran Kurikulum 2013), (2) standar isi kurikulum 2013 edisi revisi 2016 (Permendikbud Nomor 24 Tahun 2016 Lampiran 2 Tentang Kompetensi Inti dan Kompetensi Dasar Bahasa Indonesia SMP), dan (3) dokumen lain yang mendukung.

Analisis materi apresiasi sastra pada buku teks Bahasa Indonesia tingkat SMP ini dilakukan dengan lembar penilaian buku teks yang dibuat dengan memperhatikan aspek materi, penyajian, bahasa, dan grafika yang mengacu pada instrumen penilaian buku pelajaran dari Pusat Kurikulum 
dan Perbukuan. Penilian mengacu pada pedoman penskoran dan kriteria penilaian yang telah disusun oleh Pusat Kurikulum dan Perbukuan. Pada telaah isi materi, terdapat tiga aspek penilaian dan sebelas subaspek penilaian, rinciannya ada pada tabel 2 berikut ini.

Tabel 2 Pedoman Penskoran dan Kriteria Penilaian Aspek Isi Buku Teks Pelajaran

\begin{tabular}{|c|c|c|c|c|}
\hline No & Aspek & Subaspek & Skor & Kriteria \\
\hline \multirow[t]{2}{*}{1} & \multirow[t]{2}{*}{$\begin{array}{l}\text { Kesesuaian uraian } \\
\text { materi dengan KI dan } \\
\text { KD }\end{array}$} & $\begin{array}{l}\text { 1.Kelengkapan materi apresiasi sastra } \\
\text { (puisi, prosa, drama) }\end{array}$ & \multirow[t]{11}{*}{$1-4$} & \multirow{11}{*}{$\begin{array}{l}1 \text { : sangat } \\
\text { kurang } \\
2: \text { kurang } \\
3 \text { : baik } \\
4 \text { : sangat } \\
\text { baik }\end{array}$} \\
\hline & & $\begin{array}{l}\text { 2.Kedalaman materi apresiasi sastra } \\
\text { (puisi, prosa, drama) }\end{array}$ & & \\
\hline \multirow[t]{4}{*}{2} & \multirow[t]{4}{*}{ Keakuratan materi } & $\begin{array}{l}\text { 3. Keakuratan dalam pemilihan teks sastra } \\
\text { (puisi, prosa, drama) }\end{array}$ & & \\
\hline & & 4. Keakuratan dalam konsep dan teori & & \\
\hline & & 5. Keakuratan dalam pemilihan contoh & & \\
\hline & & 6. Keakuratan dalam pelatihan & & \\
\hline \multirow[t]{5}{*}{3} & \multirow[t]{5}{*}{$\begin{array}{l}\text { Materi pendukung } \\
\text { pembelajaran }\end{array}$} & $\begin{array}{l}\text { 7. Kesesuaian dengan perkembangan } \\
\text { ilmu }\end{array}$ & & \\
\hline & & $\begin{array}{l}\text { 8. Kesesuaian fitur/contoh/latihan/ } \\
\text { rujukan }\end{array}$ & & \\
\hline & & 9. Pengembangan wawasan kebhinekaan & & \\
\hline & & $\begin{array}{l}\text { 10. Pengembangan wawasan kebangsaan } \\
\text { dan integrasi bangsa }\end{array}$ & & \\
\hline & & $\begin{array}{l}\text { 11. Tidak mengandung unsur SARA, } \\
\text { HAKI, pornografi, dan bias (gender } \\
\text { wilayah, dsb) }\end{array}$ & & \\
\hline & & $\begin{array}{l}\text { Kriteria Rerata: } \\
2-2,9=\text { kurang; } 3-3,9=\text { baik; } 4-5=\end{array}$ & . & \\
\hline
\end{tabular}

Secara metodologis, prosedur analisis menggunakan model alir dengan mencakup tiga alir terpadu, yaitu: (1) reduksi data, (2) penyajian data, dan (3) verifikasi (Miles \& Huberman, 1992:17; Rohidi, 2011:234).

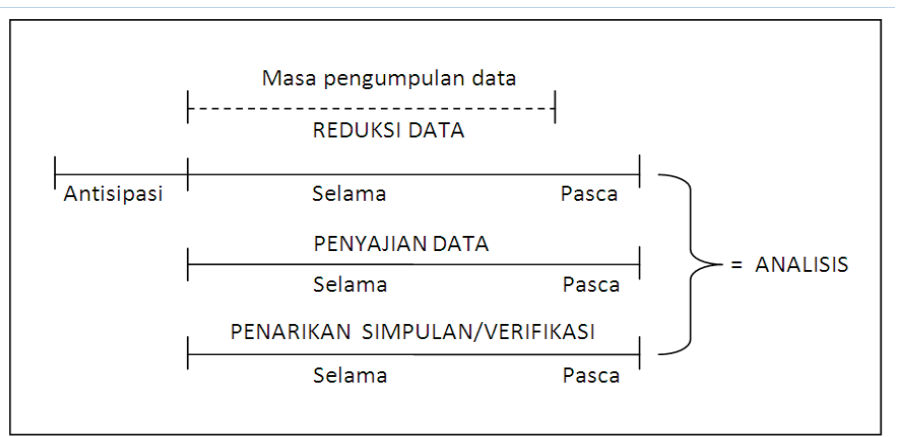

Gambar 2. Bagan Prosedur Analisis Data Model Alir

Sumber: Matthew B. Miles \& A.M. Huberman (Rohidi, 2012) 


\section{HASIL PENELITIAN DAN PEMBAHASAN}

\section{Hasil Penelitian}

\section{Kesesuaian Materi Apresiasi Puisi}

Materi pembelajaran apresiasi sastra yang terdapat pada buku teks Bahasa Indonesia SMP meliputi materi pembelajaran apresiasi puisi, prosa, dan drama. Pertama, materi apresiasi puisi pada buku teks SMP pada Kompetensi Dasar di kelas VII, VIII, dan IX. Terdapat lima KD yang berkaitan dengan konsep apresiasi sastra. Adapun hasil penilaian kesesuian materi apresiasi puisi memperoleh kriteria 'kurang', rinciannya dapat dilihat pada tabel berikut.

Tabel 3 Rekapitulasi Kesesuaian Materi Pembelajaran Apresiasi Puisi pada Buku Teks SMP

\begin{tabular}{|c|l|c|}
\hline No & \multicolumn{1}{|c|}{ Kompetensi Dasar } & Skor \\
\hline 1 & $\begin{array}{l}\text { Kelas VII, KD 3.13 Mengidentifikasi informasi (pesan, rima, dan pilihan kata) } \\
\text { dari puisi rakyat (pantun, syair, dan bentuk puisi rakyat setempat) yang dibaca } \\
\text { dan didengar }\end{array}$ & 2,72 \\
\hline 2 & $\begin{array}{l}\text { Kelas VII, KD 3.14 Menelaah struktur dan kebahasaan puisi rakyat (pantun, syair, } \\
\text { dan bentuk puisi rakyat setempat) yang dibaca dan didengar }\end{array}$ & 2,81 \\
\hline 3 & $\begin{array}{l}\text { Kelas VIII KD 3.7 Mengidentifikasi unsur-unsur pembangun teks puisi yang } \\
\text { diperdengarkan atau dibaca }\end{array}$ & 3 \\
\hline 4 & $\begin{array}{l}\text { Kelas VIII KD 4.7 Menyimpulkan unsur-unsur pembangun dan makna teks puisi } \\
\text { yang diperdengarkan atau dibaca }\end{array}$ & 3 \\
\hline 5 & $\begin{array}{l}\text { Kelas VIII KD 3.8 Menelaah unsur-unsur pembangun teks puisi (perjuangan, } \\
\text { lingkungan hidup, kondisi sosial, dan lain-lain) yang diperdengarkan atau dibaca. }\end{array}$ & 3,45 \\
\hline & Rata-Rata & 2,99 \\
\hline & Kriteria & Kurang \\
\hline
\end{tabular}

\section{Kesesuaian Materi Apresiasi Prosa}

Kedua, materi apresiasi prosa pada buku teks SMP terdiri atas sebelas KD. Adapun persebarannya merata pada kelas VII, VIII, dan IX. Adapun hasil penilaian kesesuaian materi ajar apresiasi prosa mendapat kriteria 'kurang', rinciannya dapat dilihat pada tabel berikut.

Tabel 4 Rekapitulasi Kesesuaian Materi Pembelajaran Apresiasi Prosa pada Buku Teks SMP

\begin{tabular}{|c|l|c|}
\hline No & \multicolumn{1}{|c|}{ KD } & Skor \\
\hline 1 & $\begin{array}{l}\text { Kelas VII, KD 3.3, mengidentifikasi unsur-unsur teks narasi (cerita imajinasi) yang } \\
\text { dibaca dan didengar }\end{array}$ & 2,81 \\
\hline 2 & $\begin{array}{l}\text { Kelas VII, KD 3.4, menelaah struktur dan kebahasaan teks narasi (cerita imajinasi) } \\
\text { yang dibaca dan didengar }\end{array}$ & 3,09 \\
\hline 3 & $\begin{array}{l}\text { Kelas VII, KD 3.15, mengidentifikasi informasi tentang fabel/legenda daerah } \\
\text { setempat yang dibaca dan didengar }\end{array}$ & 3,09 \\
\hline 4 & $\begin{array}{l}\text { Kelas VII, KD 3.16, menelaah struktur dan kebahasaan fabel/legenda daerah } \\
\text { setempat yang dibaca dan didengar }\end{array}$ & 3 \\
\hline
\end{tabular}




\begin{tabular}{|c|l|c|}
\hline No & \multicolumn{1}{|c|}{ KD } & Skor \\
\hline 5 & $\begin{array}{l}\text { Kelas VIII, KD 3.17, menggali dan menemukan informasi dari buku fiksi dan } \\
\text { nonfiksi yang dibaca }\end{array}$ & 3,27 \\
\hline 6 & $\begin{array}{l}\text { Kelas IX KD 3.5 Mengidentifikasi unsur pembangun karya sastra dalam teks cerita } \\
\text { pendek yang dibaca atau didengar }\end{array}$ & 2,7 \\
\hline 7 & $\begin{array}{l}\text { Kelas IX KD 4.5 Menyimpulkan unsur-unsur pembangun karya sastra dengan } \\
\text { bukti yang mendukung dari cerita pendek yang dibaca atau didengar }\end{array}$ & 2,81 \\
\hline 8 & $\begin{array}{l}\text { Kelas IX KD 3.6 Menelaah struktur dan aspek kebahasaan cerita pendek yang } \\
\text { dibaca atau didengar }\end{array}$ & 2,7 \\
\hline 9 & $\begin{array}{l}\text { Kelas IX KD 3.11 Mengidentifikasi isi ungkapan simpati, kepedulian, empati, atau } \\
\text { perasaan pribadi dari teks cerita inspiratif yang dibaca dan didengar }\end{array}$ & 2,45 \\
\hline 10 & $\begin{array}{l}\text { Kelas IX KD 4.11Menyimpulkan isi ungkapan simpati, kepedulian, empati atau } \\
\text { perasaan pribadi dalam bentuk cerita inspiratif yang dibaca dan didengar }\end{array}$ & 2,45 \\
\hline 11 & Kelas IX KD 3.12 Menelaah struktur, kebahasaan, dan isi teks cerita inspiratif & 2,45 \\
\hline & Rata-rata & 2,8 \\
\hline & Kriteria & Kurang \\
\hline
\end{tabular}

\section{Kesesuaian Materi Apresiasi Drama}

Ketiga, materi apresiasi drama pada buku teks SMP terdiri atas tiga KD. Ketiganya terdapat pada materi kelas VIII. Adapun hasil penilaian kesesuaian materi ajar apresiasi drama mendapat kriteria 'kurang', rinciannya dapat dilihat pada tabel berikut.

Tabel 5 Rekapitulasi Kesesuaian Materi Pembelajaran Apresiasi Sastra pada Buku Teks SMP

\begin{tabular}{|c|l|c|}
\hline No & \multicolumn{1}{|c|}{ KD } & Skor \\
\hline 1 & $\begin{array}{l}\text { Kelas VIII, KD 3.15, mengidentifikasi unsur-unsur drama (tradisional dan } \\
\text { moderen) yang disajikan dalam bentuk pentas atau naskah }\end{array}$ & 2,9 \\
\hline 2 & $\begin{array}{l}\text { Kelas VIII, KD 4.15, menginterpretasi drama (tradisional dan modern) yang } \\
\text { dibaca dan ditonton/didengar }\end{array}$ & 2,9 \\
\hline 3 & $\begin{array}{l}\text { Kelas VIII, KD 3.16, menelaah karakteristik unsur dan kaidah kebahasaan } \\
\text { dalam teks drama yang berbentuk naskah atau pentas }\end{array}$ & 2,9 \\
\hline Rata-rata & 2,9 \\
\hline Kriteria & Kurang \\
\hline
\end{tabular}

Berdasarkan rekapitulasi kesesuaian materi pembelajaran apresiasi sastra yang meliputi apresiasi puisi, apresiasi prosa, dan apresiasi drama, ketiganya menunjukkan hasil "kurang layak" karena reratanya berada pada julat 2,00-2,99. Oleh sebab itu, dapat ditarik simpulan bahwa aspek isi pada materi apresiasi sastra pada buku teks Bahasa Indonesia SMP belum memenuhi standardisasi kelayakan. Visualisasi lebih jelas dapat dilihat pada diagram berikut ini. 


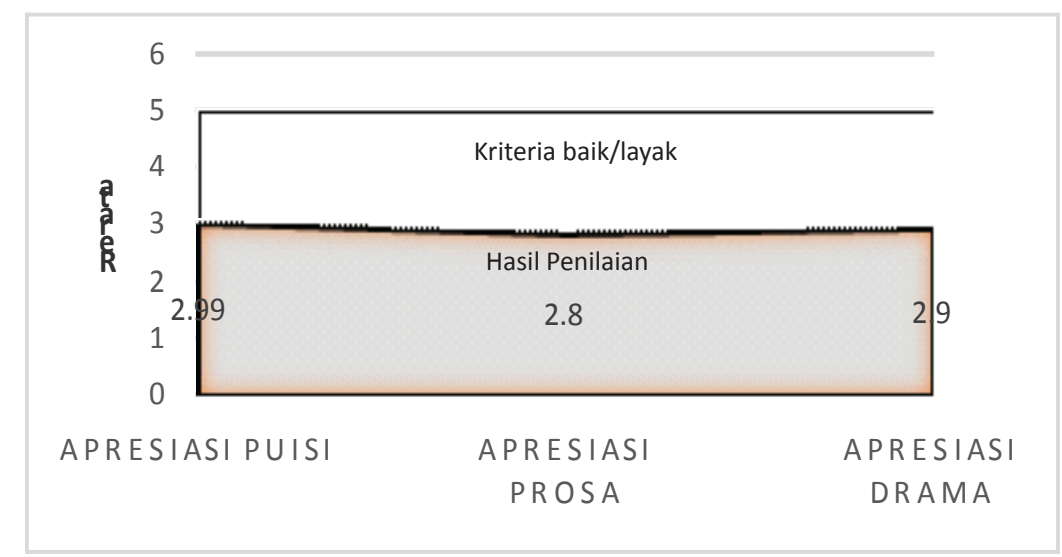

\section{Gambar 3. Diagram Area Aspek Kelayakan Materi Apresiasi Sastra Buku Teks Bahasa Indonesia SMP}

\section{Pembahasan}

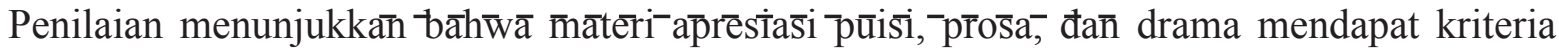
kurang layak. Adapun beberapa hal yang menjadi temuan kekurangan tersebut antara lain: (1) penjabaran materi yang tidak lengkap dari indikator yang dikembangkan, (2) penjabaran materi tidak sesuai indikator, (3) ketidakkonsistenan contoh penjelas dengan konsep yang disampaikan, (4) kegiatan yang dilakukan tidak sesuai indikator, dan (5) beberapa bagian tidak ada contoh penjelas

Pertama, penjabaran materi yang tidak lengkap dari indikator yang dikembangkan, salah satunya terdapat pada kelas VII KD 3.13, yakni mengidentifikasi informasi (pesan, rima, dan pilihan kata) dari puisi rakyat (pantun, syair, dan bentuk puisi rakyat setempat) yang dibaca dan didengar. Berdasarkan KD tersebut, indikator yang dapat dikembangkan adalah: (1) menjelaskan pesan, rima, pilihan kata pantun, (2) menjelaskan pesan, rima, pilihan kata syair, dan (3) menjelaskan pesan, rima, pilihan kata gurindam.

Materi KD 3.13 yang dipaparkan pada buku teks halaman 165-171 dengan judul bab "Mewarisi Nilai Luhur dan Mengkreasikan Puisi Rakyat" dan judul subbab "Mengenal dan Memahami Puisi Rakyat", terdapat kesalahan penomoran KD di halaman 165, yang mencantumkan KD 3.9; 4.9; 3.10; dan 4.10 seharusnya $3.13 ; 4.13 ; 3.14$; dan 4.14 . Ihwal lain yang lebih krusial adalah materi dan langkah pembelajaran yang dikembangkan tidak mengacu pada indikator yang semestinya. Adapun matriks perbedaannnya dapat disimak pada tabel berikut ini. 
Tabel 6. Perbandingan Kegiatan Pembelajara di Buku Teks dengan yang Semestinya

\begin{tabular}{|l|l|}
\hline $\begin{array}{c}\text { Langkah Pembelajaran pada Buku } \\
\text { Teks }\end{array}$ & \multicolumn{1}{c|}{$\begin{array}{c}\text { Langkah Pembelajaran yang Semestinya } \\
\text { Dikembangkan }\end{array}$} \\
\hline $\begin{array}{l}\text { membaca puisi rakyat, (2) } \\
\text { mendaftar kata berima, (3) }\end{array}$ & $\begin{array}{l}\text { (1) membaca puisi rakyat, (2) mendaftar kata berima, } \\
\text { menemukan kata berima utuh, (4) } \\
\text { menemukan kata berima sebagian } \\
\text { (5) mememukan kata berima utuh, (4) menemukan kata } \\
\text { berima sebagian, (5) menjelaskan pesan pada puisi } \\
\text { rakyair, dan gurindam, dan (6) mengidentifikasi pilihan kata pada puisi } \\
\text { menyimpulkan ciri pantun, syair } \\
\text { dan gurindam) }\end{array}$ \\
$\begin{array}{l}\text { rakyat, (7) menjelaskan pilihan kata pada puisi rakyat, } \\
\text { (8) membandingkan pantun, syair, dan gurindam, dan }\end{array}$ \\
(9) menyimpulkan ciri pantun, syair dan gurindam).
\end{tabular}

Kedua, penjabaran materi tidak sesuai indikator, misalnya terdapat pada Kelas VII KD 3.3 Mengidentifikasi unsur-unsur teks narasi (cerita imajinasi) yang dibaca dan didengar prosa. Indikator yang dikembangkan dari KD tersebut antara lain: (1) menjelaskan unsur intrinsik teks narasi (cerita imajinasi), dan (2) menjelaskan unsur ekstrinsik teks narasi (cerita imajinasi).

Ketidaksesuaian materi yang dijabarkan terdapat pada buku teks Bahasa Indonesia SMP Kelas VII halaman 45-54. Adapun unsur cerita yang dipaparkan hanya terbatas pada unsur intrinsik yang tidak lengkap, memang penulis buku lebih menekankan pada perbedaan teks narasi biasa denga teks narasi fantasi. Namun, kelengkapan materi yang dijabarkan dari indikator tetap menjadi unsur utama yang harus dipenuhi.Pada gambar 4 akan ditunjukkan tampilan materi tersebut.

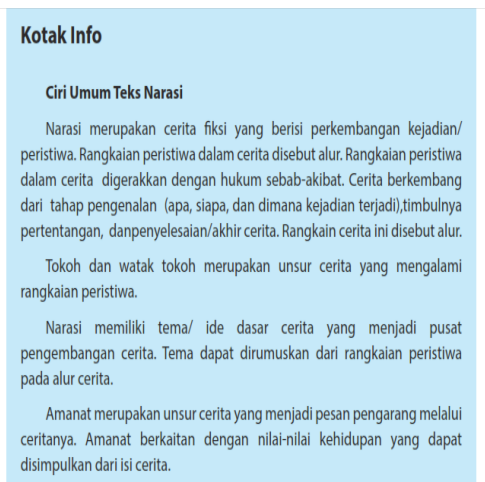

\section{Gambar 4. Unsur Teks Narasi pada Buku Teks Kelas VIIi Halaman 50}

Pada buku teks halaman 50, unsur intrinsik teks narasi yang dipaparkan hanya tokoh, tema, dan amanat. Unsur-unsur intrinsik yang lain seperti penokohan, alur, latar, amanat, dan gaya bahasa tidak dicantumkan dalam unsur intrinsik teks narasi, khususnya narasi fantasi.

Ketiga, ketidakkonsistenan contoh penjelas dengan konsep yang disampaikan, salah satunya terdapat pada Kelas VII KD 3.14 Menelaah struktur dan kebahasaan puisi rakyat (pantun, syair, dan bentuk puisi rakyat setempat) yang dibaca dan didengar. Adapun indikator yang dapat dikembangkan dari KD tersebut yakni: (1) menelaah struktur puisi rakyat, dan (2) menelaah kebahasaan puisi rakyat. KD tersebut dikembangkan menjadi materi ajar di buku teks Bahasa Indonesia SMP Kelas VII halaman 179-186. 
Ketidakkonsistenan contoh penejlas dengan konsep yang disampaikan terdapat pada contoh pantun yang ditampilkan. Contoh pantun tersebut tidak sesuai dengan konsep ciri pantun yang dijelaskan. Adapun tampilannya dapat dilihat pada gambar 5 berikut.

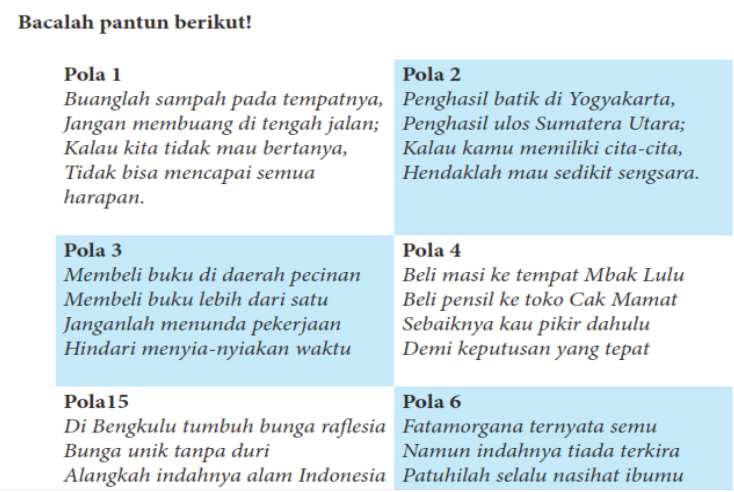

\section{Gambar 5. Contoh Pantun pada Buku Teks Bahasa Indonesia SMP Halaman 179}

Pada pola 2, pantun yang dijadikan contoh adalah:

"Penghasil batik di Yogyakarta,

Penghasil ulos di Sumatera Utara,

Kalau kamu memiliki cita-cita,

Hendaklah mau sedikit sengsara."

Pantun tersebut berima a-a-a-a. Hal ini tentu tidak sesuai dengan konsep yang sudah dipaparkan sebelumnya, yakni salah satu ciri-ciri pantun adalah rima akhir setiap baris adalah a-b-a-b. Adapun tampilan buku teks yang menyatakan hal tersebut dapat dilihat pada gambar 6 berikut ini.

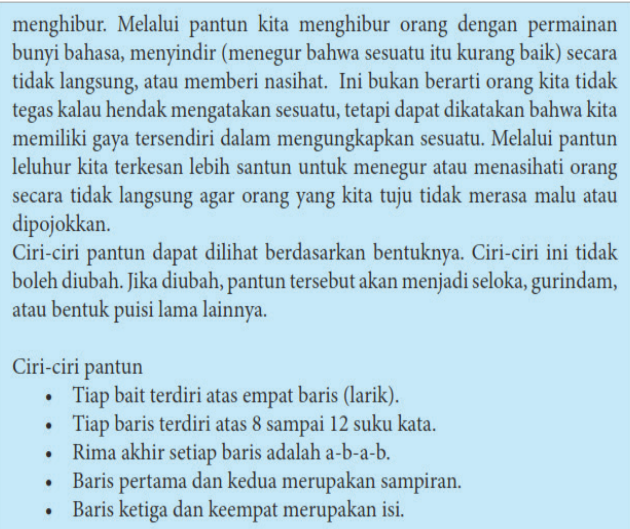

Gambar 6. Ciri-Ciri Pantun pada Buku Teks Bahasa Indonesia SMP Kelas VII Halaman 173

Keempat, kegiatan yang dilakukan tidak sesuai indikator, misalnya pada Kelas VII KD 3.4 Menelaah struktur dan kebahasaan teks narasi (cerita imajinasi) yang dibaca dan didengar. Berdasarkan 
KD tersebut, indikator yang dapat dikembangkan antara lain: (1) menelaah struktur teks narasi (cerita imajinasi), dan (2) menelaah kebahasaan teks narasi (cerita imajinasi). KD tersebut dikembangan mejadi materi ajar pada buku teks Bahasa Indonesia kelas VII SMP pada halaman 60-73 dengan subbab "Menelaah Struktur dan Bahasa Cerita Fantasi".

Adapun kegiatan pembelajaran yang dikembangkan pada KD tersebut antara lain: (1) menelaah struktur cerita fantasi: (a) menguraikan ciri bagian struktur cerita fantasi, (b) menelaah variasi pengungkapan struktur cerita fantasi, (c) menguraikan ragam alur cerita, (d) membuat telaah teks cerita dari segi strukturnya, (e) menguraikan prinsip penggunaan bahasa pada cerita fantasi, (f) menyunting cerita dari segi bahasa, dan (g) menelaah hasil melengkapi cerita fantasi. Ketidaksesuaian indikator terdapat pada langkah (f) dan (g). Tampilan buku teks dapat dilihat pada gambar berikut.

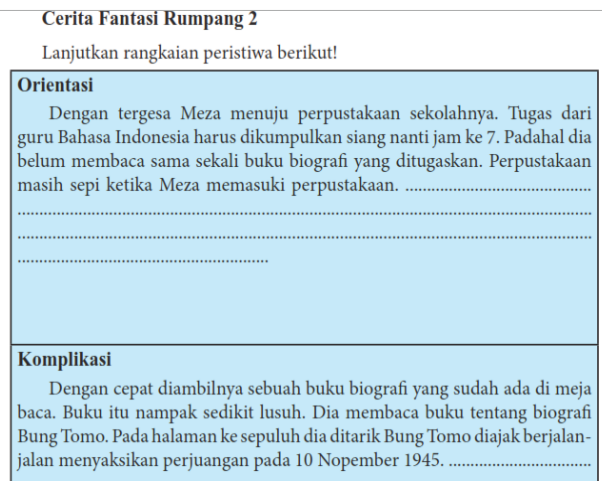

Gambar 7. Buku Teks Bahasa Indonesia SMP Kelas VII Halaman 72

Kegiatan menyunting cerita, melengkapi cerita rumpang, bahkan sampai dengan menelaah hasil melengkapi cerita tidak sesuai dengan indikator "menelaah kebahaasaan cerita". Hal tersebut sesungguhnya sudah melampaui batas-batas kegiatan ada Kompetensi Inti pengetahuan (kognitif) yang semestinya berhenti pada tahapan "menelaah" tanpa harus melampauinya ke arah keterampilan.

Selain itu, kegiatan yang tidak sesuai dengan indikator juga terdapat pada Kelas VIII KD 3.7 Mengidentifikasi unsur-unsur pembangun teks puisi yang diperdengarkan atau dibaca. KD tersebut dijabarkan pada buku teks Bahasa Indonesia SMP Kelas VIII pada halaman 91-101. KD tersebut dijabarkan dalam beberapa kegiatan. Kegiatan pembelajaran yang pertama yakni "Menemukan UnsurUnsur Pembentuk Teks Puisi" dengan materi pertama yang dijabarkan yaitu "Pengertian Puisi".

Pada materi Pengertian Puisi, kegiatan yang dikembangkan berdasarkan pada pendekatan konstruktivistik. Mulanya, disajikan puisi "Hujan Bulan Juni” karya Sapardi Djoko Damono lalu dikembangkan beberapa pertanyaan pemantik, seperti yang tercantum pada Gambar 8 berikut ini.

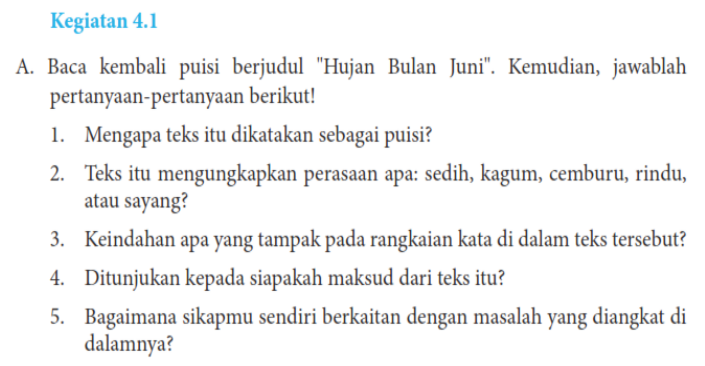

Gambar 8. Pertanyaan Pemantik pada Buku Teks Bahasa Indonesia Kelas VIII Halaman 93 
Pertanyaan-pertanyaan pemantik tersebut seharusnya menjadi upaya agar peserta didik dapat menarik simpulan ihwal pengertian puisi yang menjadi pembahasan utama, ternyata pada kegiatan selanjutnya tidak dibahas penarikan simpulan ihwal pengertian puisi. Jadi, kegiata pembelajaran yang ditampilkan pada buku teks tentu tidak sesuai dengan tujuan pembelajaran.

Kelima, tidak ada contoh penjelas. Beberapa bagian pada buku teks SMP tidak terdapat contoh penjelas untuk menyelesaikan kegiatan pembelajaran. Contoh penjelas bermanfaat untuk mempermudah peserta didik dalam memahami dan mengaplikasikan kegiatan pembelajaran dalam buku teks. Misalnya, pada halaman 202 buku teks Bahasa Indonesia SMP Kelas VIII, tidak terdapat contoh penjelas pada "Watak tokoh dalam cerita" dan "Kondisi tokoh dalam Kehidupan Nyata". Dengan tidak adanya contoh penjelas, peserta didik daat mengalami kebingungan apalagi jika tidak disertai konteks yang jelas.

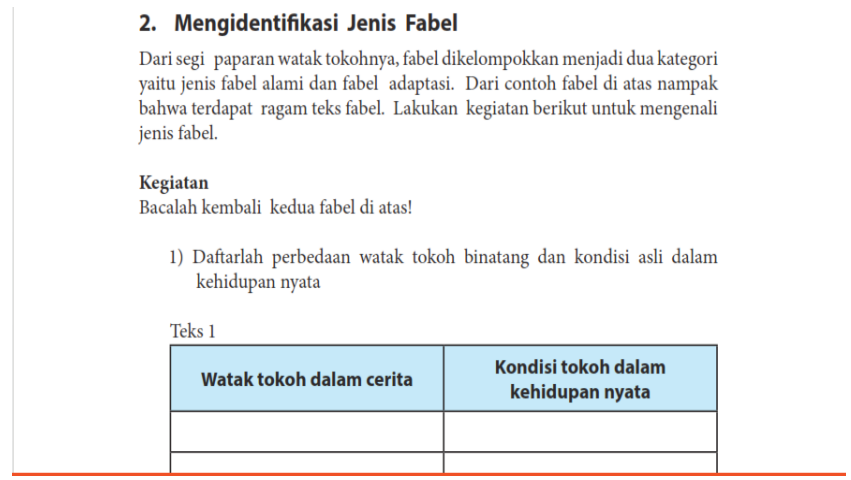

\section{Gambar 9. Buku Teks Bahasa Indonesia Kelas VIII Halaman 202}

\section{PENUTUP}

Penilaian menunjukkan bahwa materi apresiasi puisi, prosa, dan drama pada buku teks Bahasa Indonesia SMP mendapat kriteria kurang atau tidak layak. Adapun beberapa hal yang menjadi temuan kekurangan tersebut antara lain: (1) penjabaran materi yang tidak lengkap dari indikator yang dikembangkan, (2) penjabaran materi tidak sesuai indikator, (3) ketidakkonsistenan contoh penjelas dengan konsep yang disampaikan, (4) kegiatan yang dilakukan tidak sesuai indikator, dan (5) beberapa bagian tidak ada contoh penjelas

\section{DAFTAR PUSTAKA}

Aminuddin. 2002. Pengantar Apresiasi Karya Sastra. Bandung: Sinar baru Algesindo Offset.

Amri, Sofan. 2013. Pengembangan \& Model Pembelajaran dalam Kurikulum 2013. Jakarta: Prestasi Pustakaraya

Baribin, Raminah. 1990. Teori dan Apresiasi Puisi. Semarang : IKIP Semarang Press. 
Darmiyati, Zuchdi. 1993. Panduan Penelitian Analisis Konten. Yogyakarta: IKIP Yogya Press.

Endraswara, Suwardi . 2002. Metode Pengajaran Apresiasi Sastra. Yogyakarta: Radhita Buana.

Haryati, Nas. 2013. "Apresiasi Prosa". Handout Perkuliahan. Semarang: Universitas Negeri Semarang.

Kepmendikbud Nomor 116/P/2016 tentang Penetapan Buku Teks Pelajaran Kurikulum 2013.

Miles, H B. \& Heberman A M. 1992. Analisis Data Kualitatif (terj. Tjetjep Rohendi Rohidi). Jakarta: UI Press.

Moleong, Lexy J. 2000. Metodologi Penelitian Kualitatif. Bandung: PT. Remaja Rosdakarya.

Muslich, Masnur. 2010. Text Book Writing: Dasar-dasar Pemahaman, Penulisan, dan Pemakaian Buku Teks. Ar-Ruzz Media: Yogyakarta.

Permendikbud Nomor 24 Tahun 2016 Lampiran 2 Tentang Kompetensi Inti dan Kompetensi Dasar Bahasa Indonesia SMP.

Puskurbuk. 2008. Pedoman Penulisan Buku Nonteks: Buku Pengayaan, Referensi, dan Panduan Pendidik. Jakarta: Depdiknas. 